\title{
Eksplorasi Bakteri Selulolitik pada Ekosistem Mangrove
}

\author{
(Exploration of Cellulolytic Bacteria in the Mangrove Ecosystem)
}

\author{
Djanang Sukoco ${ }^{1}$, Fikrinda $^{1}$, Hifnalisa ${ }^{1^{*}}$ \\ ${ }^{1}$ Program Studi Ilmu Tanah, Fakultas Pertanian, Universitas Syiah Kuala \\ Corresponding author: hifnalisa@ unsyiah.ac.id
}

\begin{abstract}
Abstrak. Bakteri selulolitik dapat dijumpai pada lingkungan seperti ekosistem hutan mangrove. Keberadaannya pada ekosistem mangrove sangat penting untuk dekomposisi serasah magrove tersebut. Penelitian ini bertujuan untuk mengetahui adanya bakteri selulolitik pada ekosistem hutan mangrove dan potensinya dalam mendegradasi selulosa secara semi kuantitatif. Metode penelitian ini meliputi pengambilan sampel tanah, isolasi bakteri selulolitik dan uji kemampuan mendegradasi selulosa. Isolasi bakteri dilakukan dengan metode cawan tuang dan pada medium Carboxy Methyl Celullose (CMC). Uji kemampuan degradasi oleh bakteri selulolitik dilakukan pada medium dengan sumber karbon CMC dan daun mangrove. Parameter pengamatannya mengukur aktivitas selulolitik secara semi kuantitatif dan karakterisasi bakteri selulolitik. Hasil penelitian ini menunjukkan bakteri selulolitik yang terdapat di ekosistem mangrove berkisar antara $1,1 \times 10^{4} \mathrm{SPK} \mathrm{g}^{-1}$ tanah sampai 40,9x10 $\mathrm{SPK} \mathrm{g}^{-1}$ tanah. Populasi bakteri selulolitik rata-rata asal tanah mangrove bakau kurap18,16x10 $\mathrm{SPK}^{-1}$, api-api $12,98 \times 10^{4} \mathrm{SPK} \mathrm{g}^{-1}$ dan bakau minyak $4,94 \times 10^{4} \mathrm{SPK} \mathrm{g}^{-1}$. Bakteri selulolitik yang memiliki aktivitas selulolitik tertinggi pada medium dengan sumber karbon $\mathrm{CMC}$ adalah isolat $\mathrm{RM}_{2.1} ; \mathrm{RA}_{5.4} ; \mathrm{AA}_{4.4}$ dengan rasio zona bening berturut-turut 5,2;4,4;2,5 dan pada medium dengan sumber karbon daun mangrove adalah isolat $\mathrm{RA}_{4.8} ; \mathrm{AA}_{2.1} ; \mathrm{RM}_{1.1}$ dengan rasio zona bening berturut-turut 2,$3 ; 1,2 ; 1,2$.
\end{abstract}

Kata kunci: Bakteri Selulolitik, Degradasi Selulosa, Ekosistem, Mangrove.

\begin{abstract}
Cellulolytic bacteria can be found in environments such as mangrove forest ecosystems. Its presence in the mangrove ecosystem is very important for the decomposition of the magrove litter. This study aims to determine the presence of cellulolytic bacteria in mangrove forest ecosystems and their potential in semiquantitative cellulose degradation. This research method includes soil sampling, isolation of cellulolytic bacteria and testing the ability to degrade cellulose. Bacterial isolation was carried out by the pour cup method and on Carboxy Methyl Celullose (CMC) medium. The degradation ability test by cellulolytic bacteria was carried out on a medium with CMC carbon source and mangrove leaves. The observational parameters measure semiquantitative cellulolytic activity and characterization of cellulolytic bacteria. The results of this study showed that cellulolytic bacteria in the mangrove ecosystem ranged from 1,1x104 $\mathrm{SPK} \mathrm{g}^{-1}$ soil to 40,9x104 $\mathrm{SPK} \mathrm{g}^{-1}$ soil. The average population of cellulolytic bacteria from mangrove mangrove soil was ringworm 18,16x104 SPK $\mathrm{g}^{-1}$,

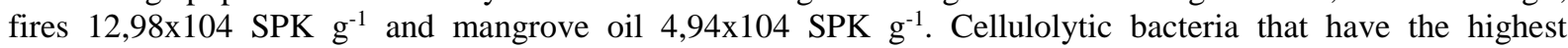
cellulolytic activity on medium with $\mathrm{CMC}$ carbon sources are isolates $\mathrm{RM}_{2.1} ; \mathrm{RA}_{5.4} ; \mathrm{AA}_{4.4}$ with clear zone ratios of 5,$2 ; 4,4 ; 2,5$ and on medium with carbon sources mangrove leaves were $\mathrm{RM}_{1.1} ; \mathrm{AA}_{2.1} ; \mathrm{RA}_{4.8}$ isolates with a clear zone ratio of 2,$3 ; 1,2 ; 1,2$, respectively.
\end{abstract}

Keywords: Cellulolytic Bacteria, Cellulose Degradation, Ecosystems, Mangroves.

\section{PENDAHULUAN}

Bakteri selulolitik dapat dijumpai pada lingkungan seperti ekosistem hutan mangrove. Keberadaannya pada ekosistem mangrove sangat penting untuk dekomposisi serasah magrove tersebut. Bakteri ini mampu mendegradasi selulosa secara enzimatis melalui aktivitas enzim selulase yang dikeluarkan atau dihasilkan dari siklus hidupnya. Bakteri selulolitik berperan dalam proses penting di alam seperti digunakan untuk proses pengomposan kulit kopi (Nurfitriani dan Handayanto, 2017), sebagai bioaktivator pengolahan limbah selulosa menjadi kompos (Azizah et al., 2014), menghasilkan protein dengan menggunakan bahan dasar selulosa dan terlibat dalam proses pencernaan hewan ternak (Aiman dan Astuti, 2012). Penelitian ini bertujuan untuk mengetahui adanya bakteri selulolitik pada ekosistem hutan mangrove dan potensinya dalam mendegradasi selulosa secara semi kuantitatif. Keberadaan 
bakteri selulolitik pada ekosistem mangrove sangat penting untuk dekomposisi serasah magrove tersebut. Berdasarkan pemikiran itu, penelitian ini dilakukan untuk mengetahui adanya bakteri selulolitik di ekosistem mangrove dan kemampuan bakteri selulolitik mendegradasi selulosa.

\title{
METODE PENELITIAN
}

\section{Tempat Penelitian}

Pengambilan sampel tanah dilakukan pada kawasan hutan mangrove di Desa Gampong Pandee, Kecamatan Kuta Radja, Kota Banda Aceh. Isolasi dan uji aktivitas selulolitik semi kuantitatif bakteri selulolitik dilakukan di Laboratorium Biologi Tanah Fakultas Pertanian Universitas Syiah Kuala. Penelitian dilakukan pada November 2018 sampai dengan April 2019.

\begin{abstract}
Alat dan Bahan
Alat-alat yang digunakan pada penelitian ini adalah bor tanah, autoklaf, shaker, spatula, jarum ose, neraca analitik, bunsen, inkubator, lemari es, mikroskop, kantong plastik, penggaris, thermometer, Total Dissolved Solids (TDS) meter dan peralatan gelas lainnya.

Bahan-bahan yang digunakan pada penelitian ini adalah sample tanah di rhizosfer beberapa tanaman mangrove (Rhizophora mucronata, Rhizophora apiculata dan Acrostichum aureum) daun tanaman mangrove (Rhizophora mucronata, Rhizophora apiculata dan Acrostichum aureum), Bacto agar, Carboxy Methyl Celullose (CMC), aluminium foil, kapas, Congo red, $\mathrm{NaCl}$, spiritus, alkohol $70 \%$, aquades dan bahan kimia lainnya.
\end{abstract}

\section{Metode Penelitian}

Penelitian ini merupakan penelitian deskriptif. Isolasi bakteri selulolitik tanah menggunakan metode cawan tuang. Kemudian dilakukan pengujian bakteri selulolitik untuk mendegradasi selulosa secara semi kuantitatif pada medium dengan sumber karbon CMC dan daun mangrove.

\section{Pengambilan Sampel Tanah}

Sampel tanah diambil pada rhizosfer dari tiga jenis mangrove yang dominan di kawasan hutan mangrove di Desa Gampong Pandee yaitu api-api (Acrostichum aureum), bakau minyak (Rhizophora apiculata) dan bakau kurap (Rhizophora mucronata). Pada setiap jenis mangrove tersebut diambil lima sampel tanah dan setiap sampel merupakan komposit dari lima titik pemboran tanah di rhizosfer mangrove. Pengambilan sampel dilakukan pada kedalaman 20 $\mathrm{cm}$. Saat pengambilan sampel tanah, dilakukan pengukuran suhu tanah, $\mathrm{pH}$ tanah dan salinitas tanah.

\section{Isolasi dan Pemurnian Bakteri Selulolitik}

Bakteri selulolitik diisolasi dari tiga rhizosfer mangrove yaitu api-api (Acrostichum aureum), bakau minyak (Rhizophora apiculata) dan bakau kurap (Rhizophora mucronata). Isolasi bakteri selulolitik dilakukan dengan metode cawan tuang dengan medium CMC dan pembuatan pengenceran bertingkat sebanyak 4 kali pengenceran dari setiap sampel tanah. Bakteri selulolitik hanya diisolasi dari seri pengenceran ke 3 dan 4 kemudian dipipet ke dalam cawan petri lalu dituangkan medium CMC agar. Cawan petri diputar agar suspensi merata dan dibiarkan hingga medium menjadi padat, kemudian disimpan pada inkubator selama lima hari. Setelah bakteri tumbuh pada setiap cawan petri maka dihitung jumlah koloni bakteri 
yang tumbuh. Bakteri-bakteri yang memiliki koloni yang besar dan membentuk zona bening mewakili setiap sampel tanah dipilih sebanyak 20 isolat dari masing-masing ketiga tanaman mangrove kemudian dimurnikan.

\section{Uji Kemampuan Bakteri Selulolitik Mendegradasi Selulosa}

Uji degradasi selulosa bakteri selulolitik dilakukan pada medium selulosa dengan dua sumber karbon yang berbeda yaitu CMC dan daun mangrove. Sebanyak satu ose isolat terpilih ditanamkan pada medium $\mathrm{CMC}$ dan daun mangrove. Isolat kemudian dinkubasi selama empat hari dan diuji seabanyak tiga kali. Setelah masa inkubasi berakhir, media ditetesi dengan larutan Congo red 1\% dan dibilas dengan larutan $\mathrm{NaCl} 1 \mathrm{M}$. Bakteri selulolitik yang dapat mendegradasi selulosa diindikasikan dengan adanya zona bening (halo zone) di sekitar koloni bakteri.

\section{Aktivitas Selulolitik}

Aktivitas selulolitik dari bakteri ditentukan dengan melihat nilai rasio zona bening dari pengukuran diameter zona bening yang terbentuk pada setiap cawan petri berisi bakteri selulolitik dan diameter koloni (Gambar 1). Perhitungan nilai rasio zona bening bakteri selulolitik dilakukan dengan rumus:

Keterangan :

$$
\mathrm{R}=\mathrm{Z} / \mathrm{K}
$$

R : Rasio Zona Bening Z : Diameter Zona Bening K : Diameter Koloni

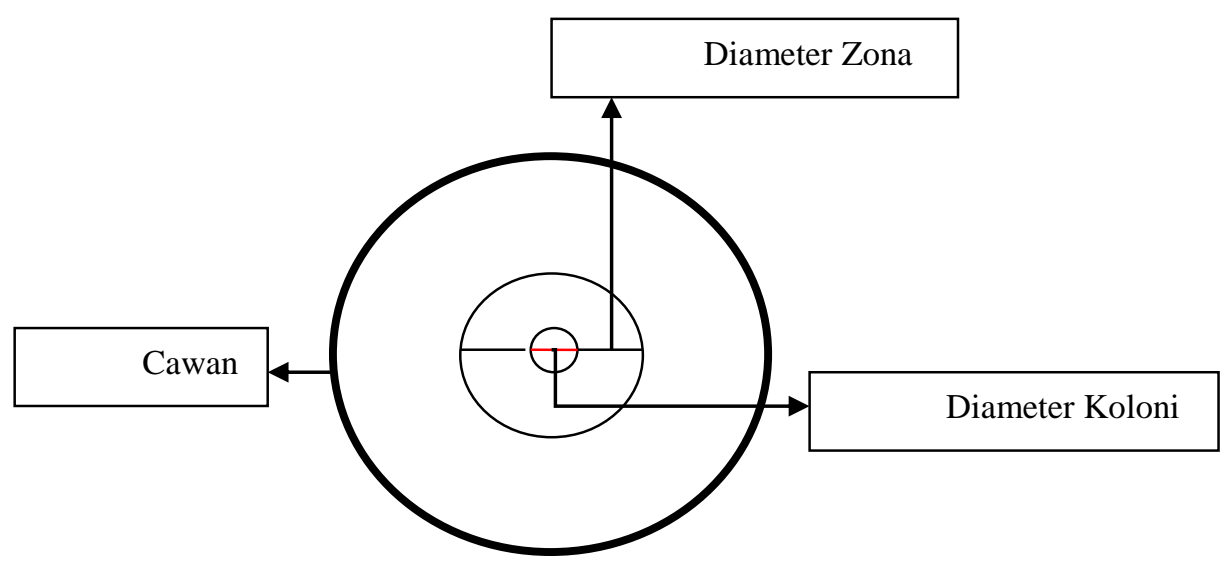

Gambar 1. Skema pengukuran zona bening dan diameter koloni bakteri selulolitik

\section{Karakterisasi Bakteri Selulolitik}

Sebanyak 10 isolat bakteri selulolitik dipilih berdasarkan kemampuanya mendegradasi selulosa baik pada medium sumber karbon CMC dan daun mangrove dengan nilai rasio ratarata tertinggi dari tiap isolat. Isolat bakteri selulolitik dengan nilai rata-rata rasio zona bening yang tinggi dikarakterisasi. Karakterisasi bakteri dilakukan dengan melihat ciri morfologi seperti warna, bentuk, tepian, dan elevasi. 


\section{HASIL DAN PEMBAHASAN}

\section{Jumlah Koloni Bakteri Selulolitik}

Rata-rata jumlah koloni bakteri selulolitik dapat dilihat pada Tabel 1. Tabel 1 menunjukkan bahwa bakteri selulolitik dijumpai pada 13 sampel dari 15 sampel tanah yang diisolasi. Jumlah rata-rata bakteri selulolitik pada ekosistem mangrove bakau kurap (Rhizopora mucronata), api-api (Acrostichum aureum) dan bakau minyak (Rhizopora apiculata) yaitu 18,16; 12,98 dan 4,94. Jika dilihat dari ketiga ekosistem tersebut populasi rata-rata bakteri selulolitik terbanyak yaitu pada ekosistem mangrove bakau kurap.

Tabel 1. Jumlah Bakteri Selulolitik pada Ekosistem Mangrove

\begin{tabular}{|c|c|c|}
\hline Isolat & Jenis Mangrove & $\begin{array}{c}\text { Rata-rata Jumlah Koloni Bakteri } \\
\text { Selulolitik } \\
\left(\ldots \times 10^{4} \mathrm{SPK} \mathrm{g}^{-1} \text { tanah }\right) \\
\end{array}$ \\
\hline $\mathrm{AA}_{1}$ & \multirow{5}{*}{ Api-api (Acrostichum aureum) } & 8,1 \\
\hline $\mathrm{AA}_{2}$ & & 12,0 \\
\hline $\mathrm{AA}_{3}$ & & 19,4 \\
\hline $\mathrm{AA}_{4}$ & & 25,4 \\
\hline $\mathrm{AA}_{5}$ & & 0 \\
\hline & Rata-rata & 12,98 \\
\hline $\mathrm{RA}_{1}$ & \multirow{5}{*}{ Bakau Minyak (Rhizopora apiculata) } & 0 \\
\hline $\mathrm{RA}_{2}$ & & 0 \\
\hline $\mathrm{RA}_{3}$ & & 1,1 \\
\hline $\mathrm{RA}_{4}$ & & 15,1 \\
\hline $\mathrm{RA}_{5}$ & & 8,5 \\
\hline & Rata-rata & 4,94 \\
\hline $\mathrm{RM}_{1}$ & \multirow{5}{*}{ Bakau Kurap (Rhizopora mucronata) } & 9,5 \\
\hline $\mathrm{RM}_{2}$ & & 18,4 \\
\hline $\mathrm{RM}_{3}$ & & 40,9 \\
\hline $\mathrm{RM}_{4}$ & & 19,3 \\
\hline $\mathrm{RM}_{5}$ & & 2,7 \\
\hline & Rata-rata & 18,16 \\
\hline
\end{tabular}

\section{Aktivitas Selulolitik Bakteri Selulolitik Asal Mangrove}

Sebanyak 52 isolat bakteri selulolitik yang berasal dari ekosistem mangrove diuji kemampuannya dalam mendegradasi selulosa pada medium dengan sumber karbon CMC dan daun mangrove. Isolat tersebut berasal dari tanah ekosistem mangrove api-api (Acrostichum aureum) didapat 15 isolat, dari tanah jenis mangrove bakau minyak (Rhizopora apiculata) didapat 19 isolat dan dari tanah jenis mangrove bakau kurap (Rhizopora mucronata) didapat 18 isolat. Aktivitas selulolitik ditandai dengan adanya zona bening pada sebuah koloni bakteri yang mendegradasi selulosa (Rudiansyah, et al. 2017). Nilai rasio zona bening bakteri selulolitik diperoleh dari diameter zona bening dan diameter koloni bakteri. 
Tabel 2. Nilai Rasio Zona Bening Bakteri Selulolitik pada Sumber Karbon CMC dan Daun Mangrove Asal Tanah api-api (Acrostichum aureum)

\begin{tabular}{clrc}
\hline \multirow{2}{*}{ No } & \multirow{2}{*}{ Kode Isolat } & \multicolumn{2}{c}{ Reta-rata } \\
\cline { 3 - 4 } & & Medium CMC & Medium daun mangrove \\
\hline $\mathbf{1}$ & $\mathrm{AA}_{1.1}$ & 1,2 & 0 \\
$\mathbf{2}$ & $\mathrm{AA}_{1.2}$ & 1,4 & 0 \\
$\mathbf{3}$ & $\mathrm{AA}_{1.3}$ & 1,7 & 0 \\
$\mathbf{4}$ & $\mathrm{AA}_{1.4}$ & 1,6 & 0 \\
$\mathbf{5}$ & $\mathrm{AA}_{1.5}$ & 2,0 & 0 \\
$\mathbf{6}$ & $\mathrm{AA}_{1.6}$ & 2,3 & 0 \\
$\mathbf{7}$ & $\mathrm{AA}_{2.1}$ & 1,7 & 1,2 \\
$\mathbf{8}$ & $\mathrm{AA}_{2.2}$ & 1,5 & 0 \\
$\mathbf{9}$ & $\mathrm{AA}_{3.1}$ & 1,6 & 0 \\
$\mathbf{1 0}$ & $\mathrm{AA}_{3.2}$ & 1,3 & 0 \\
$\mathbf{1 1}$ & $\mathrm{AA}_{4.1}$ & 1,5 & 0 \\
$\mathbf{1 2}$ & $\mathrm{AA}_{4.2}$ & 1,3 & 0 \\
$\mathbf{1 3}$ & $\mathrm{AA}_{4.3}$ & 1,2 & 0 \\
$\mathbf{1 4}$ & $\mathrm{AA}_{4.4}$ & 2,5 & 1,0 \\
$\mathbf{1 5}$ & $\mathrm{AA}_{4.5}$ & 1,2 & 0 \\
\hline
\end{tabular}

Tabel 3. Nilai Rasio Zona Bening Bakteri Selulolitik pada Sumber Karbon CMC dan Daun Mangrove Asal Tanah bakau minyak (Rhizopora apiculata)

\begin{tabular}{clcc}
\hline \multirow{2}{*}{ No } & \multirow{2}{*}{ Kode Isolat } & Redium CMC & Rata-rata \\
\cline { 2 - 4 } & & 1,6 & 0 \\
\hline $\mathbf{1}$ & RA $_{4.1}$ & 1,4 & 0 \\
$\mathbf{2}$ & RA $_{4.2}$ & 1,6 & 0 \\
$\mathbf{3}$ & RA $_{4.3}$ & 1,8 & 0 \\
$\mathbf{4}$ & RA $_{4.4}$ & 1,2 & 0 \\
$\mathbf{5}$ & RA $_{4.5}$ & 1,6 & 0 \\
$\mathbf{6}$ & RA $_{4.6}$ & 1,6 & 0 \\
$\mathbf{7}$ & RA $_{4.7}$ & 1,4 & 2,3 \\
$\mathbf{8}$ & RA $_{4.8}$ & 1,2 & 0 \\
$\mathbf{9}$ & RA $_{4.9}$ & 1,8 & 0 \\
$\mathbf{1 0}$ & RA $_{4.10}$ & 1,6 & 0 \\
$\mathbf{1 1}$ & RA $_{5.1}$ & 1,7 & 0 \\
$\mathbf{1 2}$ & RA $_{5.2}$ & 1,5 & 1,8 \\
$\mathbf{1 3}$ & RA $_{5.3}$ & 4,4 & 1,5 \\
$\mathbf{1 4}$ & RA $_{5.4}$ & 1,3 & 0 \\
$\mathbf{1 5}$ & RA $_{5.5}$ & 1,4 & 0 \\
$\mathbf{1 6}$ & RA $_{5.6}$ & 1,4 & 0 \\
$\mathbf{1 7}$ & RA $_{5.7}$ & 1,6 & 2,0 \\
$\mathbf{1 8}$ & RA $_{5.8}$ & 1,7 & 0 \\
$\mathbf{1 9}$ & RA $_{5.9}$ & & \\
\hline
\end{tabular}


Tabel 4. Nilai Rasio Zona Bening Bakteri Selulolitik pada Sumber Karbon CMC dan Daun Mangrove Asal Tanah bakau kurap (Rhizopora mucronata)

\begin{tabular}{clcc}
\hline \multirow{2}{*}{ No } & \multirow{2}{*}{ Kode Isolat } & Medium CMC & Rata-rata \\
\cline { 3 - 4 } & & 1,7 & Medium daun mangrove \\
\hline $\mathbf{1}$ & $\mathrm{RM}_{1.1}$ & 1,4 & 1,2 \\
$\mathbf{2}$ & $\mathrm{RM}_{1.2}$ & 1,5 & 0 \\
$\mathbf{3}$ & $\mathrm{RM}_{1.3}$ & 5,2 & 0 \\
$\mathbf{4}$ & $\mathrm{RM}_{2.1}$ & 1,3 & 1,1 \\
$\mathbf{5}$ & $\mathrm{RM}_{2.2}$ & 1,4 & 0 \\
$\mathbf{6}$ & $\mathrm{RM}_{2.3}$ & 1,3 & 0 \\
$\mathbf{7}$ & $\mathrm{RM}_{2.4}$ & 1,4 & 0 \\
$\mathbf{8}$ & $\mathrm{RM}_{2.5}$ & 1,3 & 0 \\
$\mathbf{9}$ & $\mathrm{RM}_{2.6}$ & 2,1 & 0 \\
$\mathbf{1 0}$ & $\mathrm{RM}_{3.1}$ & 3,2 & 0 \\
$\mathbf{1 1}$ & $\mathrm{RM}_{3.3}$ & 1,6 & 0,8 \\
$\mathbf{1 2}$ & $\mathrm{RM}_{4.1}$ & 2,1 & 0 \\
$\mathbf{1 3}$ & $\mathrm{RM}_{4.2}$ & 1,3 & 0 \\
$\mathbf{1 4}$ & $\mathrm{RM}_{4.3}$ & 2,6 & 0 \\
$\mathbf{1 5}$ & $\mathrm{RM}_{4.5}$ & 2,2 & 1,0 \\
$\mathbf{1 6}$ & $\mathrm{RM}_{5.1}$ & 2,0 & 0 \\
$\mathbf{1 7}$ & $\mathrm{RM}_{5.2}$ & 2,0 & 0 \\
$\mathbf{1 8}$ & $\mathrm{RM}_{5.3}$ & & 0 \\
\hline
\end{tabular}

Tabel 2 menunjukkan isolat bakteri selulolitik AA4.4 asal tanah mangrove api-api (Acrostichum aureum) memiliki aktivitas selulolitik selulolitik tertinggi dengan nilai rasio zona bening rata-rata sebesar 2,5 yang diuiji pada medium CMC sedangkan pada uji dengan medium daun mangrove hanya isolat $\mathrm{AA}_{2.1}$ dan $\mathrm{AA}_{4.4}$ yang memiliki nilai rasio rata-rata sebesar 1,2 dan 1,0. Aktivitas selulolitik ditandai dengan adanya zona bening pada sebuah koloni bakteri yang mendegradasi selulosa (Rudiansyah, et al. 2017).

Tabel 3 menunjukkan aktivitas selulolitik tertinggi adalah isolat RA F.4 $_{5}$ yang berasal dari tanah mangrove bakau minyak (Rhizopora apiculata) dengan nilai rasio zona bening rata-rata sebesar 4,4 yang diuji pada medium CMC sedangkan pada uji medium daun mangrove hanya 4 isolat bakteri selulolitik yang memiliki aktivitas selulolitik. Isolat bakteri selulolitik tersebut yaitu $\mathrm{RA}_{4.8}, \mathrm{RA}_{5.3}, \mathrm{RA}_{5.4}$ dan $\mathrm{RA}_{5.8}$. Hasilnya menunjukkan dari keempat isolat tersebut, satu isolat yang nilai rasio zona bening rata-ratanya paling tinggi yaitu isolat RA4.8 sebesar 2,3. Bakteri selulolitik yang mempunyai kemampuan mencerna selulosa dengan baik maka bakteri tersebut akan membentuk zona bening (Dwismar et al., 2013).

Tabel 4 menunjukkan isolat bakteri selulolitik $\mathrm{RA}_{2.1}$ asal tanah mangrove bakau kurap (Rhizopora mucronata) merupakan isolat dengan aktivitas selulolitik tertinggi dengan rasio zona bening rata-rata sebesar 5,2 yang diuji pada medium CMC sedangkan pada uji medium daun mangrove hanya 4 isolat bakteri selulolitik yang menunjukkan aktivitas selulolitik. Isolat bakteri selulolitik tersebut yaitu $\mathrm{RM}_{1.1}, \mathrm{RM}_{2.1}, \mathrm{RM}_{3.3}$ dan $\mathrm{RM}_{4.5}$. Nilai rasio zona bening ratarata tertinggi yaitu $\mathrm{RM}_{1.1}$ sebesar 1,2. Perbedaan rasio zona bening disebabkan oleh perbedaan isolat bakteri selulolitik yang ditemukan serta perbedaan dalam aktivitas selulolitiknya (Puspawati, et al. 2018).

Aktivitas bakteri selulolitik bervariasi dari setiap isolat. Setiap bakteri memiliki kemampuan yang berbeda-beda dalam mendegradasi selulosa, tergantung dari jenis bakteri tersebut. Nilai rasio zona bening rata-rata berkisar 1,0 sampai 5,2 untuk uji pada medium dengan sumber karbon CMC, sedangkan dari hasil uji pada medium dengan sumber karbon daun mangrove nilai rasio zona bening rata-rata berkisar 0,8 sampai 2,3. Nurrochman (2015) 
menyatakan besar kecilnya nilai rasio zona bening yang terbentuk menandakan kuat lemahnya bakteri dalam mendegradasi selulosa.

\section{Karakterisai Bakteri Selulolitik Terpilih}

Pemilihan bakteri selulolitik dilihat dari kemampuan bakteri yang dapat mendegradasi selulosa pada kedua medium dengan sumber carbon CMC dan daun mangrove.

Tabel 5. Bakteri Selulolitik Terpilih yang diuji pada Medium Sumber Karbon CMC dan Daun Mangrove

\begin{tabular}{clcc}
\hline \multirow{2}{*}{ No } & \multirow{2}{*}{ Kode Isolat } & \multicolumn{2}{c}{ Nilai rata-rata rasio zona bening } \\
\cline { 3 - 4 } $\mathbf{1}$ & $\mathrm{AA}_{2.1}$ & Sumber Karbon CMC & Sumber Karbon Daun Mangrove \\
$\mathbf{2}$ & $\mathrm{AA}_{4.4}$ & 1,7 & 1,2 \\
$\mathbf{3}$ & $\mathrm{RA}_{4.8}$ & 2,5 & 1,0 \\
$\mathbf{4}$ & $\mathrm{RA}_{5.3}$ & 1,4 & 2,3 \\
$\mathbf{5}$ & $\mathrm{RA}_{5.4}$ & 1,5 & 1,8 \\
$\mathbf{6}$ & $\mathrm{RA}_{5.8}$ & 4,4 & 1,5 \\
$\mathbf{7}$ & $\mathrm{RM}_{1.1}$ & 1,6 & 2,0 \\
$\mathbf{8}$ & $\mathrm{RM}_{2.1}$ & 1,7 & 1,2 \\
$\mathbf{9}$ & $\mathrm{RM}_{3.3}$ & 5,2 & 1,1 \\
$\mathbf{1 0}$ & $\mathrm{RM}_{4.5}$ & 3,2 & 1,3 \\
\hline
\end{tabular}

Sebanyak 10 isolat bakteri yang terpilih berdasarkan hasil uji degradasi selulosa bakteri selulolitik pada media selulosa dengan sumber karbon CMC dan pada sumber karbon serasah daun mangrove. Rasio zona bening rata-rata isolat $\mathrm{RM}_{2.1}$ tertinggi pada uji degradasi medium selulosa dengan sumber karbon CMC, tetapi isolat tersebut rasio zona bening rata-ratanya rendah pada uji degradasi medium selulosa dengan sumber karbon daun mangrove, sedangkan pada uji degradasi media selulosa dengan sumber karbon serasah daun mangrove nilai ratarata rasio tertinggi yaitu isolat $\mathrm{RA}_{4.8}$, tetapi isolat tersebut rasio zona bening rata-ratanya rendah pada uji degradasi media selulosa dengan sumber karbon CMC.

\section{KESIMPULAN}

Bakteri selulolitik terdapat di ekosistem mangrove dengan populasi berkisar antara $1,1 \times 10^{4} \mathrm{SPK} \mathrm{g}^{-1}$ tanah sampai $40,9 \times 10^{4} \mathrm{SPK} \mathrm{g}^{-1}$ tanah. Jumlah populasi bakteri selulolitik pada ekosistem mangrove diantaranya bakau kurap $18,16 \times 10^{4} \mathrm{SPK}^{-1}$, api-api $12,98 \times 10^{4}$ SPK $\mathrm{g}^{-1}$ dan bakau minyak $4,94 \times 10^{4} \mathrm{SPK}^{-1}$. Bakteri selulolitik yang memiliki aktivitas selulolitik tertinggi pada medium dengan sumber karbon $\mathrm{CMC}$ adalah isolat $\mathrm{RM}_{2.1}, \mathrm{RA}_{5.4}$ dan AA 4.4 dengan rasio zona bening berturut-turut sebesar 5,2;4,4;2,5. Bakteri selulolitik yang memiliki aktivitas selulolitik tertinggi pada medium dengan sumber karbon daun mangrove adalah isolat $\mathrm{RA}_{4.8}, \mathrm{AA}_{2.1}$ dan $\mathrm{RM}_{1.1}$ dengan rasio zona bening berturut-turut sebesar 2,$3 ; 1,2 ; 1,2$. Isolat $\mathrm{RM}_{2.1}$ dan $\mathrm{RA}_{4.8}$ adalah bakteri selulolitik potensial yang berasal dari ekosistem mangrove di Gampong Pandee.

\section{DAFTAR PUSTAKA}

Aiman, U dan N. Astuti. 2012. Mikroorganisme selulolitik dari berbagai substrat peranannya dalam meningkatkan kualitas hijauan makanan ternak. J. AgriSains. 3 (4): 71-87.

Azizah, S. N., K. Muzakhar dan S. Arimurti. 2014. Isolasi dan karakterisasi bakteri selulolitik asal jerami padi di persawahan Bogor Barat. J. Ilmiah Kesehatan. 2 (1): 19-27. 
Dwismar, R., M. Baharuddin dan Syamsidar. 2013. Isolasi dan uji enzim selulase dari bakteri simbion larva kupu-kupu famili Cossidae terhadap variasi lama inkubasi. J. Al-kimia. 1 (1): 76-85.

Nurfitriani, S dan E. Handayanto. 2017. Dekomposisi kulit kopi oleh bakteri selulolitik yang diisolasi dari timbunan kulit kopi di perkebunan Kalibendo Jawa Timur. J. Tanah dan Sumberdaya lahan. 4 (2): 503-514.

Nurrochman, F. 2015. Eksplorasi bakteri selulolitik dari tanah hutan mangrove Baros Kretek Kecamatan Bantul Yogyakarta. Skripsi. Program Studi Pendidikan Biologi Fakultas Keguruan dan Ilmu Pendidikan Universitas Muhammadiyah Surakarta, Jawa Tengah.

Puspawati, I, M, I., I. W. D. Atmaja dan N. W. S. Sutari. 2018. Eksplorasi bakteri selulolitik dari sampah organik kota Denpasar. J. Agroteknologi Tropika. 7 (3): 363-373.

Rudiansyah, D., Rahmawati dan Rafdinal. 2017. Eksplorasi bakteri selulolitik dari tanah hutan mangrove Peniti Kecamatan Segedong Kabupaten Mempawah. J. Protobiont. 6 (3): 255-262. 